\title{
A Primer on Exporting to Belize ${ }^{1}$
}

\author{
Christina D. Storz, Timothy G. Taylor, and Gary F. Fairchild ${ }^{2}$
}

\section{Introduction}

Every year the U.S. Department of State publishes extensive Country Commercial Guides for a large number of countries. These guides provide a great deal of information useful to individuals interested in developing exports markets either through direct exports or through direct foreign investment. This paper provides an abridged version of the Country Commercial Guide for Belize as well as supplemental information of direct relevance to agribusiness firms It is hoped that the information contained in this report provides a useful starting point for individuals interested in exploring export or investment opportunities in Belize.

Note: County Commercial Guides are available for U.S. exporters from the National Trade Data Bank's CD-ROM or via the Internet. Please contact Stat-USA by telephone (1-800) STAT-USA for more information. Country Commercial Guides can be accessed via the World Wide Web at http://www.stat-usa.gov, http://www.state.gov, and http://www.mac.doc.gov. They can also be ordered as a hard copy or on diskette from the National Technical Information Service (NTIS) by telephone (1-800) 553-NTIS. American exporters seeking general export information/assistance and country-specific commercial information should contact the U.S. Department of Commerce, Trade Information Center by telephone (1-800) USA-TRADE; or by fax (202) 482-4473.

\section{Economic and Political Overview}

Belize is the second smallest and least populated country in Central America. It has an open, private sector-led economy based mainly on export agriculture and services. Though Belize is the smallest consumer market in the region, it has unique advantages as a potential trading partner, such as proximity to the United States, efficient air and sea transportation, and strong cultural influences from North America. The Belize dollar is pegged to the U.S. dollar at the rate of two Belize dollars to one U.S. dollar. English is the official language of Belize.

The People's United Party administration plans to continue a mixed monetary and fiscal policy, which entails lowering the lending rates and liquidity and reserve requirements as well as borrowing heavily to boosting public sector spending on infrastructure. Selected public enterprises were privatized, with the receipts reinvested into high-quality, export-oriented infrastructure and an increased human resource capacity. Agricultural economic diversification and expansion of the

1. This is EDIS document FE503, a publication of the Department of Food and Resource Economics, Florida Cooperative Extension Service, Institute of Food and Agricultural Sciences, University of Florida, Gainesville, FL. Published February 2005. Please visit the EDIS website at http://edis.ifas.ufl.edu.

2. Christina D. Storz, Research Assistant; Timothy G. Taylor, Professor; and Gary F. Fairchild, Professor, Department of Food and Resource Economics, Florida Cooperative Extension Service, Institute of Food and Agricultural Sciences, University of Florida, Gainesville, FL. 
tourism industry continue to be two of the government of Belize's main economic strategies towards increased foreign exchange earnings and import substitution.

Due to the current administration's "growth economics" policy, Belize's GDP (Gross Domestic Product) growth rate of $1.7 \%$ in 1998 increased to $6.4 \%$ in 1999 and $8.2 \%$ in 2000 . However, the economy decreased in 2001 due to extreme weather events and terrorist attacks in the United States. Belize's GDP of US $\$ 805$ million in 2001 (up from US\$773 in 2000) yielded a per capita income of about US $\$ 3,134$, which is higher than most other Central American countries. This growth is attributed primarily to increases in total output of Belize's primary agricultural crops not severely affected by tropical storms (citrus, grain, and livestock) and its fast-growing tourism industry. Economic growth in 2002 was projected to be about $4 \%$.

Agriculture, the primary sector of Belize's economy, contributed $11.3 \%$ to its total GDP in 2000. After three consecutive years of growth, production yields for Belize's major agricultural products (sugar, citrus concentrate, and bananas) declined in 2001. Likewise, export earnings from marine products also declined in 2001 after three consecutive years of growth. The growing move toward freer trade may erode some of the preferential trade market arrangements Belize currently enjoys. Thus, the future of Belize's agricultural sector could be quite turbulent unless it finds ways to become more efficient. Revenues from tourism have become increasingly important and have been on a growth trend.

Foreign investors are required to register any investment with the Central Bank of Belize to facilitate the repatriation of profits and dividends. However, foreign investors in Belize are having difficulty repatriating their profits due to a tight supply of U.S. dollars in the local banking system. The government of Belize's preferred areas in which investors are encouraged to invest include agro-industries, tourism, light manufacturing, and forestry-based industries. The United States continues to be Belize's number one trading partner. In 2001, the United States imported 53.8\% of Belize's total exports and supplied $48.1 \%$ of all Belizean imports.

\section{Marketing U.S. Products and Services}

There are a number of factors that should be considered in exporting products to Belize. This section provides a brief overview of some of the critical factors that must be considered.

\section{Establishing a Business}

The following is taken from the laws of Belize, Chapter 206, Part IX. It applies to foreign companies wishing to establish an office in Belize.

- Overseas companies establishing a place of business within Belize shall, within one month of establishing a place of business, deliver the following to the Registrar for registration:

- A certified copy of the charter, statutes or memorandum and articles of the company or other instrument constituting or defining the constitution of the company, and if the instrument is not written in the English language, a certified translation thereof.

- A list of the directors and secretary of the company containing the particulars:

- In the case of an individual: Christian name and surname (past and present), permanent residential address, nationality, and business occupation.

- In the case of a corporation: corporate name and registered or principal office.

- In the case of a secretary or joint secretaries: each person's Christian name and surname (past and present), and permanent residential address.

- The names and addresses of one or more persons who are residents in Belize and are authorized to accept on behalf of the company service of process and any notices required to be served on the company.

- Every overseas company shall, in every calendar year, file with the Registrar such a statement in the form of a balance sheet as would, if it were a company incorporated in 
Belize and having a share capital, be required to be included in the annual summary.

- Every overseas company shall do the following:

- In every prospectus inviting subscriptions for its shares or debentures in Belize, state the country in which the company is incorporated.

- Conspicuously exhibit in every place where it carries on business in Belize the name of the company and the country in which the company is incorporated.

- Cause the name of the company and of the country in which it is incorporated to be stated in legible characters in all bill heads and letter paper and in all notices and other official publications of the company.

- If the liability of the members of the company is limited, cause notice of that fact to be stated in legible characters in every such prospectus as aforesaid and in all bill heads, letter paper, notices, and other official publications of the company in Belize, and to be affixed on every place where it carries on business.

In addition, foreign companies are required to pay a registration fee of BZ\$84 (US\$42) at the office of the Registrar General in the Supreme Court Building in Belize City.

\section{Distribution / Sales Channels}

Because the local economy is extremely small, the best way for U.S. exporters to penetrate the Belizean market is to seek a local importer/wholesaler who would generally act as their agent/distributor in Belize. A typical distribution channel for an American-made product involves the U.S. manufacturer or distributor, the local importer or wholesaler (who almost always acts also as the distributor), the retailer, and finally the buyer/consumer.

\section{Agents / Distributors: Finding a Partner}

Consistent with U.S. Department of Commerce guidelines, the Economic and Commercial section of the U.S. Embassy in Belize can assist interested U.S. companies in finding agents and distributors in the country through the International Partner Search (IPS) Service. The embassy also provides the Gold Key Service (GKS), another business facilitation program, which includes personalized services and introductions to potential partners. The embassy can also supply lists of the major local firms in a particular industry to interested U.S. firms on request. Nominal fees are charged for these services on a cost-recovery basis. Interested U.S. companies should contact the U.S. Embassy in Belize or the nearest U.S. Commerce Department Export Assistance Center for detailed information.

\section{Direct Marketing}

Direct marketing in Belize by U.S. companies is rare. Normally, a local representative of the U.S. firm performs all the local marketing functions.

\section{Franchising}

Although many Belizeans are familiar with most of the popular U.S. brand names, franchising remains rare since competition in the local market is more often based on price, rather than on name recognition or perceived quality standards. Franchising in Belize currently extends to just a few well-known brand names, including Best Western in the hospitality industry; Coca-Cola and Pepsi in the soft drink industry; and Avis, Budget, Hertz, and National in the auto rental business.

\section{Joint Ventures / Licensing}

The government welcomes foreign capital into the domestic economy and supports joint venture and partnership investments whenever possible as the preferred mechanism for the employment of such capital.

\section{Selling Factors / Techniques}

Most major importers and wholesalers employ local commission agents who sell and deliver the product to the retailer. Most major supermarkets also 
deliver the product to the doorsteps of the customer. Personal contact with the clientele, therefore, is always recommended.

\section{Advertising / Trade Promotion}

Advertising in Belize is done mainly through radio, newspapers, magazines, and television. However, the use of billboards is fast gaining popularity. The Economic and Commerical Section of the U.S. Embassy in Belize puts out a quarterly newsletter titled "Commercial Opportunities." American companies are welcome to place advertisements in this publication free of charge. The U.S. Embassy also participates in two national trade events: the National Agriculture and Trade Show (normally held in May) and EXPO Belize (held in September) as part of the country's independence-day celebration. American firms are also welcome to join the U.S. Embassy's pavilion at these two trade shows.

\section{Sales Service / Customer Support}

Sales service in Belize is limited to business establishments dealing with electronic equipment, including photocopiers, typewriters, computers, and air conditioners.

\section{Product Pricing}

Certain items, including basic foodstuffs (rice, beans, sugar, bread, and flour), butane gas, and fuel, have government price controls (1987 supplies control regulations). Most items are subject to one of two sales tax rates: $12 \%$ on petroleum products, alcohol, and tobacco, and $8 \%$ on all other commodities. Staple food items (e.g., rice, beans, corn, fresh meat, flour, sugar, eggs, bread, and tortillas) are sales tax exempted.

\section{Selling to the Government}

Suppliers of U.S. products and services generally have little difficulty selling to the government of Belize. In many cases, however, success of the suppliers in selling to the government depends on their political affiliation or personal contacts with the governing party. Local suppliers who are not members of the party-of-the-day may not have the opportunity to sell to the government, and whenever they do, they may experience late payments. Numerous opportunities exist for selling to local projects that are funded by multilateral financial institutions (e.g., the Inter-American Development Bank).

In addition, the general orders, a list of government rules and regulations pertaining to the administration of the public service, govern the contractual and purchasing practices of government department and agencies. Under this order, government purchases of over US\$50,000 must be submitted for public bidding by both local and foreign companies. However, bidders for tenders for externally funded projects must comply with the procurement rules and regulations of the foreign funding organization.

\section{IPR Infringement Protection}

In May of 2000, the Belize national assembly passed a comprehensive set of Intellectual Property Rights (IPR) legislation as part of Belize's obligation under the World Trade Organization (WTO) to implement the Agreement on Trade-Related Aspects of Intellectual Property (TRIPS Agreement).

\section{Need for a Local Attorney}

It is advisable to seek legal assistance when planning to do business in Belize. The U.S. Embassy can provide a comprehensive list of the major law firms in Belize on request, as well as a list of local certified public accountants, but cannot recommend specific practitioners.

\section{Agribusiness Industry Prospects}

In 2000, Belize imported US\$221.7 million worth of goods from the United States. Of this total, $95.8 \%$ was comprised of machinery and transport equipment (US\$87.4 million), manufactured goods (US\$71 million), food and live animals (US\$30.5 million), and chemicals and related products (US\$23.5 million).

Belize has very limited local manufacturing capability, so the best prospects for U.S. agricultural exports to Belize include food processing and packaging equipment. Agro-processing is one of the top priorities of the government of Belize for 
economic development. Local demand in this industry is increasing because of local and foreign investment in agribusiness ventures.

\section{Trade Regulations and Standards}

\section{Trade Barriers}

The government of Belize implemented the final phase of CARICOM's common external tariff in April of 2000, which brought Belize's import duties on industrial products to an average of $20 \%$. There is also a variable revenue replacement duty ranging from $12 \%$ to $25 \%$ for nongoods (e.g., beer, cigarettes, and liquor).

Areas typically closed to foreign private investors include merchandising (distributive trades), sugarcane cultivation, commercial fishing (inside the barrier reef), internal transportation, and restaurants and bars.

\section{Customs Valuation}

The Belize Customs Department generally uses original commercial invoices and product catalogs to determine the value of goods coming into the country. However, there are occasional reports of harassment, pilferage, and requests for bribes to facilitate lower valuations.

Under the post-importation inspection scheme, duly authorized Customs agents will review the Customs declaration forms submitted by the local importers and verify that the declared prices on the invoices are indeed correct. This scheme is intended to recover the tremendous loss of Customs revenue resulting from under-invoicing.

\section{Standards}

The Belize Bureau of Standards promotes and encourages the maintenance and use of codes of practice, specifications, and standards. The bureau often models regulations, such as those for labeling, after other CARICOM member states. American products that have been made in accordance with the standards regulations of the United States are deemed to comply with Belize's standards regulations as well.

\section{Labeling Requirements}

The Belize Bureau of Standards has a standard for labeling and marking locally manufactured and imported products sold in Belize. The three-part standard explains, for example, that the label affixed to a product shall give a description of a good and shall provide adequate information to a potential purchaser to enable him to select the goods best suited to his needs.

\section{Temporary Entry Provisions}

The Belize Customs Department allows temporary entry or transit of certain items into Belize. Products brought in temporarily or in-transit would generally enter duty-free, providing they are not modified or transformed while in Belize. If, however, the importer later decides to modify or sell the product locally, all necessary duties must be paid at the Belize Customs Department.

\section{Import Controls}

At least 27 categories of products require import licenses prior to importation into Belize. The list includes products such as rice, beans, eggs, sugar, citrus, flour, meats, jams/jellies, pepper sauce, matches, peanuts, pasta, soap, toilet paper, beer, aerated beverages, fuel, brooms, and boats. The Ministry of Industry is expected to submit recommendations to the government for the gradual removal of these quantitative import restrictions. Belizean importers continue to complain that the process for obtaining import licenses is prone to corruption and needless red tape.

In addition, the Belize Agricultural Health Authority (BAHA), working under the Ministry of Agriculture, Fisheries, and Cooperatives (MAFC), also has its own requirements for the importation of agricultural products into Belize. For instance, BAHA requires importers of fresh plant products to obtain an import permit and to supply phytosanitary certificates and certificates of origin. Importers of live animals are also required to obtain an import permit from MAFC and to supply a zoo-sanitary certificate from the country of origin, while importers of pesticides must only obtain an import permit. 
Certain goods are generally not allowed into Belize unless they originate from another CARICOM state. The list includes peanut butter, jam, jellies, matches, pasta, beans, rice, wheat flour, and pepper sauce. Beans and rice, however, like many other locally produced agricultural products, may not be imported at all whenever there is a surplus of these products on the domestic market.

Both importers and exporters must obtain the appropriate permits prior to importing into or exporting from Belize. Importers are required to submit all original commercial invoices to the Belize Customs Department.

\section{Export Controls}

Certain products also require export licenses and/or zoo-sanitary certificates prior to exportation. The list includes cattle, pigs, fish, crustaceans and mollusk (excluding aquaculture species), logs and lumber, sugar, honey, citrus fruits, and beans.

The exportation of animals (including pets) and agricultural products from Belize require zoo-sanitary and phytosanitary certificates issued by the Belize Agricultural Health Authority in addition to export permits.

\section{Free Trade Zones / Warehouses}

The 1990 Export Processing Zone (EPZ) Act of Belize provides for companies to operate within general or special export processing zones in the country. Special EPZs are enclosed one-factory operations, and general EPZs are enclosed multi-factory operations. Belize's first EPZ covers 28.5 acres and is located eight miles from the Mexican border in the northernmost district of Corozal.

The Commercial Free Zone Management Authority (CFZMA) has full supervision authority of the CFZs within Belize. However, the autonomy of the CFZMA board has been eroded as a result of amendments to the document that provided for the establishment and operation of EPZs throughout the country to promote commercial trade and investment with neighboring countries.

\section{Membership in Free Trade Agreements}

Belize, as a CARICOM member state, has free trade agreements with Venezuela and Columbia. The country does not have agreements with either the United States or with any European Union member country. However, it does have preferential treatment from the United States under the Caribbean Basin Initiative (CBI) and from the European Union under the Lome Convention.

\section{Investment Climate in Brief}

- The Belize government typically welcomes foreign investment and encourages projects that result in increased production, diversification of the economic base, foreign exchange earnings and savings, and the transfer of technology and skills.

- Special consideration is given to export-oriented businesses established in less-developed areas.

- The Belize Trade and Investment Development Service (BELTRAIDE) serves as a one-stop shop for information to investors.

- BELTRAIDE has identified the following sectors of the economy as priority areas of investment of interest to U.S. agriculturists:

- Agriculture, agro-industries, food processing, and livestock.

- Aquaculture and horticulture.

- Deep-sea fishing and processing.

- Forestry and forestry-based industries.

- Incentives to promote and encourage investment in Belize (however, many foreign investors have complained that these investment promotion tools are rarely as open and effective as they are portrayed):

- Fiscal Incentives Act.

- Commercial Free Zone Act. 
- International Business and Public Companies Act.

- Export Processing Zone Act.

- There have been no instances where the government has expropriated or nationalized a foreign company. However, there have been several contentious cases where the government, under its right of eminent domain, appropriated land that belonged to private property owners, including some foreign investors. These expropriations were ostensibly made for public purposes, but several were uncovered as political payoffs. The government has subsequently strengthened the Ministry of Natural Resources to prevent abuses and made a good faith effort to settle claims. Nevertheless, although Belizean law requires that the government make assessments and pay appropriate compensation based on fair market value, such compensation can often take years to settle. The government of Belize allocates a very small amount of its annual budget to pay the large and growing amount of unpaid property claims.

- The Belizean government does not allow 100\% foreign ownership of an enterprise.

- An export permit and either a phytosanitary or zoo-sanitary certificate are required to export certain agricultural products (e.g., fresh fruits, livestock, and marine products).

- Belize's financial system is small, but efficient and sound. It consists of five commercial banks, one parastatal lending institution (the Development Finance Corporation), and several small credit unions.

- Historically, Belize has maintained one of the most stable political environments in the region.

- Typical of most countries in the region, Belize has its share of problems with corruption. Though bribery is illegal in Belize, laws against it are rarely enforced.

- Labor-management relations are relatively good.
- Belize has a liberal policy toward capital outflows. According to the Belize Investment Guide, the government is committed to guaranteeing repatriation of investments, profits, and returns from capital gains. However, this policy is dependent on the availability of foreign exchange in the local financial system.

\section{Business Customs}

\section{Travel Advisory and Visas}

A passport, valid for at least six months past the planned stay in Belize, along with a return ticket are required to enter the country. No visas are required from citizens of the United States, United Kingdom, or any other Commonwealth country. For such visitors, a visitor's permit for a maximum of thirty days is given on arrival at the international airport. Departure taxes and fees totaling US $\$ 15$ must be paid before leaving from the international airport or US $\$ 3.75$ from either the Santa Elena or Benque Viejo borders. It is not possible to access U.S. bank accounts through automated teller machines (ATMs) in Belize.

More detailed and updated travel information on Belize is available through the U.S. Department of State in Washington, D.C. For recorded information, telephone (202) 647-5225.

American business travelers are encouraged to obtain a copy of the "Key Officers of Foreign Service Posts: Guide for Business Representatives" available for sale from the Superintendent of Documents, U.S. Government Printing Office, Washington, D.C. 20402, by telephone (202) 512-1800, and by fax (202) 512-2250.

Business travelers to Belize seeking appointments with U.S. Embassy-Belize officials should contact the Commercial Section in advance (telephone 501-227-7161; fax 501-227-1468; email EmbreyEL2@gate.gov.

\section{Business Infrastructure}

In Belize City, Belmopan, and the district capitals, the normal business attire is an open-collar business shirt or a guayabera shirt. Business hours for the private sector are normally 8:00 a.m. to 5:00 p.m., 
Monday through Friday, with one hour for lunch. Government hours are the same, except on Fridays when offices close at 4:30 p.m. Appointments are preferred. Punctuality is advised and appreciated.

Foreign businessmen find it relatively easy to operate in Belize. International transportation is relatively good, with daily direct flights from Miami, Houston, and Dallas/Fort Worth. Ports in Belize City and Big Creek handle regularly scheduled shipping from the United States and United Kingdom.

International telecommunications are excellent and professional services, such as accountants and attorneys, are readily available. Accommodations range from deluxe hotels in Belize City to beachfront resorts to small lodges and guesthouses nationwide. All hotel guests are charged a $7 \%$ tax.

\section{Useful Web Sites}

\section{BELIZE:}

- AccessBelize.com http://www.accessbelize.com/links/ government.html

- Belize Trade and Development Services http://www.belizeinvest.org.bz

- Government of Belize Contacts http://www.belize.gov/bz/contact

\section{UNITED STATES:}

- USDA Foreign Agricultural Service http://www.fas.usda.gov

- US Export Programs Guide http://infoserv2.ita.doc.gov/ticwebsite/tic.nsf/ AF34FA880278BDD5825690D00656C6F/ F69FDCF72B7713B58525691900746F18?Open Document

- Internet Guide to Trade Leads http://infoserv2.ita.doc/gov/ticwebsite/tic.nsf/ 504ca249c786e20f85256284006da7ab/ ef7db94aef24919885266470049c1cd?OpenDocu ment

- US Trade Finance Resources http://infoserv2.ita.doc.gov/ticwebsite/tic.nsf/
AF34FA880278BDD5825690D00656C6F/ F69FDCF72B7713B58525691900746F18?Open Document

- Basic Guide to Exporting http://www.unzco.com/basicguide/index.html

\section{HEMISPHERIC:}

- Hemispheric Guide on Customs Procedures http://alca-ftaa.iadb.org/hgcp_eng.htm

- Hemispheric Trade and Tariff Database http://alca-ftaa.iadb.org/eng/ngmadb_e.htm 